\title{
Knapsack sprayers: effort required for pumping lever operation
}

\author{
Edson Lambrecht ${ }^{1^{*}}$ (D) Douglas Silva da $\operatorname{Rosa}^{1}$ (iD) Roberto Lilles Tavares Machado ${ }^{2}$ (iD

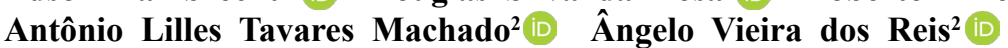

${ }^{1}$ Programa de Pós-graduação em Sistemas de Produção Agrícola Familiar, Universidade Federal de Pelotas (UFPEL), 96010-900, Pelotas, RS, Brasil. E-mail: edsonlambrecht@gmail.com. "Corresponding author.

${ }^{2}$ Departamento de Engenharia Rural (DER), Universidade Federal de Pelotas (UFPEL), Pelotas, RS, Brasil.

ABSTRACT: Various equipment, mainly manual knapsack sprayers, are used to apply agrochemicals by smallholder farmers. They are highlighted by their versatility of use and mainly by their low cost for farmers. Few operator-related studies were reported in the literature regarding the effort required to operate the knapsack sprayer lever. Knapsack sprayers were evaluated regarding the effort required to move their hand levers, reach and maintain the $300 \mathrm{kPa}$ pressure, and return to the initial position. The objective of this study was to evaluate the operator's effort to operate the hand lever using the "Super magro" biofertilizer as fluid. It was concluded that all knapsack sprayers are within the Consolidation of Labor Laws (CLT) standards regarding the effort required to operate the hand lever. However, restrictions have been reported in some manual knapsack sprayers regarding international standards.

Key words: family farming, ergonomics, upper limb effort, effort in sprayers.

Pulverizadores costais: esforço para o acionamento da alavanca de bombeamento

RESUMO: Existem diversos equipamentos utilizados na aplicação de agrotóxicos em propriedades familiares, principalmente os pulverizadores costais manuais. Estes ganham destaque pela sua versatilidade de uso e, principalmente, o baixo custo para o produtor rural. Na bibliografia foi constatado poucos estudos relacionados ao operador, quando analisado o seu esforço ao acionar a alavanca do pulverizador costal. Os pulverizadores costais foram avaliados quanto aos esforços necessários ao deslocamento da alavanca: para atingir a pressão de $300 \mathrm{kPa}$, na manutenção desta e em seu retorno para a posição inicial. Este estudo teve como objetivo avaliar os esforços do operador ao acionar a alavanca utilizando como fluido o biofertilizante composto Super Magro. Conclui-se, no que tange ao esforço para acionamento da alavanca, que todos os pulverizadores estão dentro das normas da CLT (Consolidação das Leis Trabalhistas), porém existem restrições a alguns pulverizadores costais manuais em relação às normas internacionais.

Palavras-chave: agricultura familiar, ergonomia, esforço dos membros superiores, esforço em pulverizadores.

\section{INTRODUCTION}

Manual knapsack sprayers are used to apply various products, including pesticides and biofertilizers, which are highlighted in the phytosanitary control phase in various arable crops. Spray applications are made by generating and emitting liquid particles in order to control pests, increase productivity in farms, and collaborate with the world agricultural production (SILVA et al., 2015).

Biofertilizers are considered liquid organic fertilizers. They result from fermentation of organic residues and nutrients in water, and they provide an increase in plant resistance to pest and disease attack (STUCHI, 2015).
Knapsack sprayers are used on a large scale by small, medium, and large farmers due to their great versatility. This equipment has characteristics that meet the existing needs in rural properties, as they have a low cost of acquisition and allow products to be applied in several cultures (LOPES et al., 2011 \& FREITAS, 2006).

CARVALHO et al. (2013) stated that workers, who carry a knapsack sprayer with a weight greater than $10 \mathrm{~kg}$ on their back and make constant movements, are subject to change in body posture along time of the spraying activity. This author pointed out that another important factor is associated with the spraying work in addition to the equipment weight: the repetitive operation maneuver 
usually performed by the left upper limb on the lever to generate pressure in the system. CARVALHO et al. (2013) also reported that the operator should perform this activity following established technical standards. According to these standards, hand levers must be actuated every two steps or empirically when a systematic operation is difficult for the worker to carry out. The ABNT NBR 19932-1 standard specifies minimum requirements, test methods, and performance limits for the knapsack sprayer to ensure safe use.

According to SOUZA \& SANTANA (2011), rural workers are subject to fatigue and development of musculoskeletal disorders when they use heavy equipment. These authors recommend that such workers adopt body posture training, workout gymnastics, and scheduled breaks to mitigate the risks due to the weight load of knapsack sprayers. Five-minute breaks are also recommended every fifty minutes of work for them to rest and do stretching exercises during application (SENAR, 2014). However, farmers who are users of knapsack sprayers hardly follow these recommendations in practice.

The work performed with the manual knapsack sprayer requires the operator to constantly push a lever (usually with his upper left limb), increasing the internal pump pressure to expel the suspension by means of the application boom (which is held with his right hand), directing its nozzle to the target (SENAR, 2014 \& FREITAS, 2006).

Few studies on the use of manual knapsack sprayers and their effects on the operators' health were reported in the literature. Thus, the following questions arise: What is the effort required for such an operator to push the pumping lever during application of biofertilizers? What is the consequence for the operator's health after he performs this work?

HOSTENS \& RAMON (2005) stated that repetitive effort can trigger muscle fatigue, reporting that little information is available about exertion parameters applied by the workers' upper limbs.

PHADKE et al. (1992) obtained the mean value for the maximum return (or ascending) effort $(18.7 \mathrm{~N})$ without reporting whether the right or left arm was used. They also obtained the mean values for the efforts required to generate a $300-\mathrm{kPa}$ pressure $(10.1 \mathrm{~N})$ and maintain it $(11.1 \mathrm{~N})$. These values are lower than those reported by LAMBRECHT et al. (2018), who studied different knapsack sprayers and used water as a fluid. They obtained mean values for the maximum return effort $(14.4 \mathrm{~N})$ and those for the maximum effort to generate a $300-\mathrm{kPa}$ pressure $(38.1 \mathrm{~N})$ and maintain it $(88.9 \mathrm{~N})$.
In Brazil, the Consolidation of Labor Laws (CLT) recommends the value for the maximum effort by one of the worker's upper limbs (147.1 N), whereas the NASA-STD-3000B (1995) recommends a lower maximum effort value $(71.2 \mathrm{~N})$.

Therefore, given the lack of information on the subject, the objectives of this study were to quantify the effort required for workers to push the pumping lever in knapsack sprayers using biofertilizer fluid and verify if the results are in agreement with the limits established by both the Brazilian Laws (CLT) and international recommendations (NASA-STD-3000B).

\section{MATERIAL AND METHODS}

This study was carried out in the facilities of the Nucleus for Innovation in Agricultural Machinery and Equipment (NIMEq), Universidade Federal de Pelotas (UFPel). Six brand models of sprayers were chosen. They were selected because they were the most used by local farmers and most offered by farm equipment stores in the national market. The knapsack sprayers were randomly labeled A, B, C, $\mathrm{D}, \mathrm{E}$, and $\mathrm{F}$ and evaluated for requirements, test methods, and minimum performance as established by ISO 19932-1:2013. The Guarani (model SE-20), Brudden (model S-20), Macrotop (model MPM200), Eccofer (model 201), and Jacto (models PJH 201 and XP 201) brands were evaluated, but they were not identified in the analyzes.

Each equipment was individually adapted to a bench test (Figure 1a) where the sprayer lever was actuated by means of a device. It was composed of a Scotch-Yoke ${ }^{\circledR}$ type crank handle system (Figure 1b) that transforms uniform circular motion into alternating linear motion. The mechanism drive speed was adjusted through a frequency inverter (WEG, model CFW 08; Figure 1c). This inverter allowed the rotation to vary in the range $0-1000 \mathrm{rpm}$, thus enabling to control the pump drive frequency (drives per minute) to be controlled at a frequency of $650 \mathrm{~Hz}$. This control provided a rotation of $21 \mathrm{rpm}$, allowing the sprayers to reach the necessary working pressure $(300 \mathrm{kPa})$ as determined by ISO 19932-1:2013. The pressure was controlled by a COMAM manometer with a scale in the range of 0-2.06 $\mathrm{MPa}$.

In each sprayer, the force applied to the lever (drive arm) was measured using a system with two levers in parallel. A dynamometer (digital WeiHeng hook scale, model 128), with a capacity of $400 \mathrm{~N}$ (resolution of $0.10 \mathrm{~N}$ ) was installed, allowing to read the values for forces applied to different 


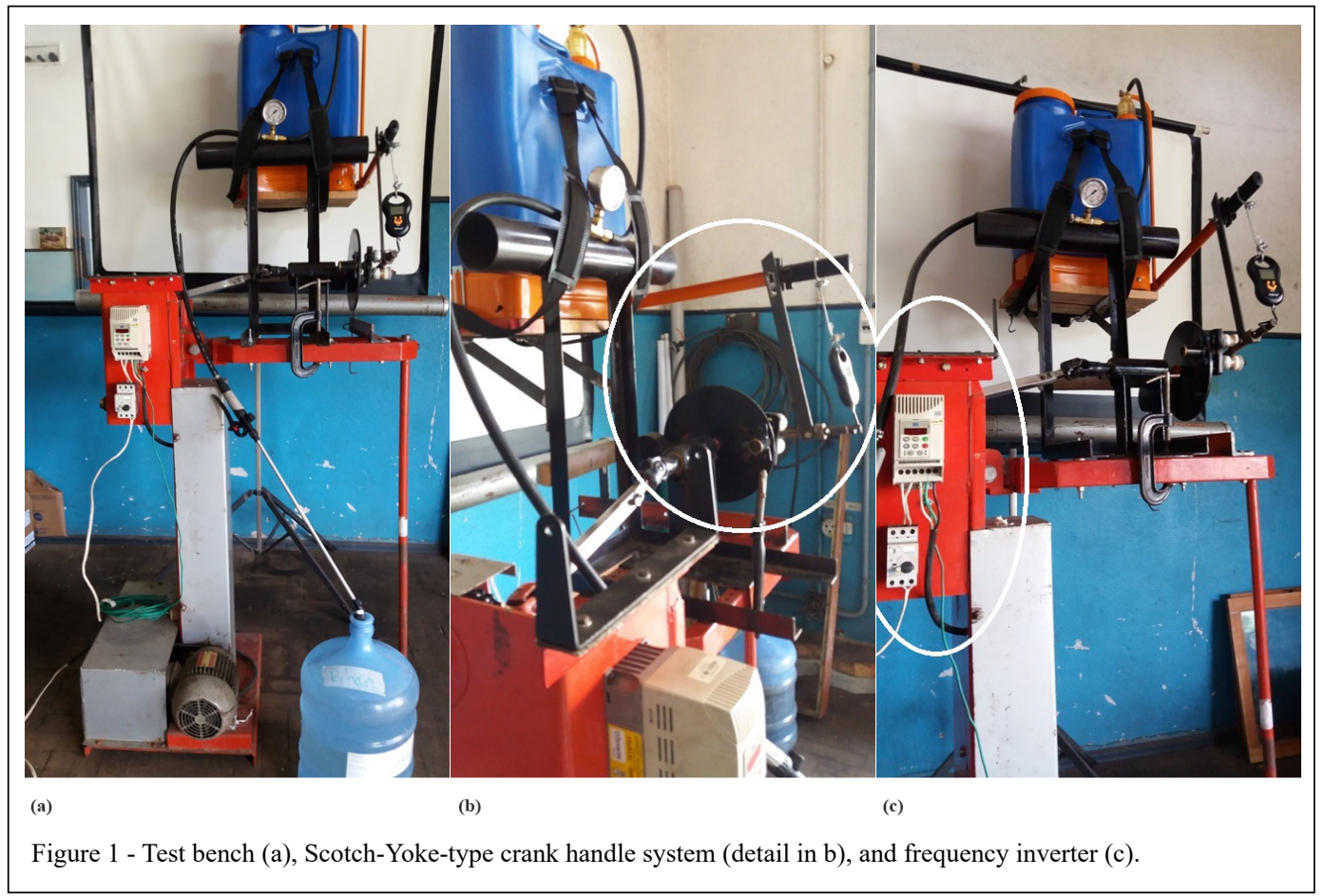

movement positions of the sprayer levers. A digital (Olympus, model VR 320) camera was used to record the readings.

In most equipment, a ceramic (Magno 11001-AD) spray nozzle with anti-drift fan-type jet was used. For this reason, this nozzle was chosen for the assays. In addition, it had a greater offer in the market and worked with the $300 \mathrm{kPa}$ pressure as established.

Analysis of variance (ANOVA) and the Tukey's (5\% probability level) and Shapiro-Wilk (W) normality tests were applied to the conditions studied (return before and after the $300 \mathrm{kPa}$ pressure was reached), considering six levels for the sprayer models (A, B, C, D, E, and F) and number of cycles as repetitions. A logarithmic transformation was applied to treatments that did not present a significant normal distribution $(p<0.05)$. The data were stored in a spreadsheet for further analysis and the "Super Magro" compound was used as biofertilizer fluid because it is the most used in organic farming practices (GUAZZELLI, RUPP, and VENTURINI, 2012). An initial aqueous mixture of the biofertilizer $(10 \%$ in $2 \mathrm{~L})$ was diluted in water as described by STUCHI (2015) to then obtain the final mixture (20 L, the capacity of sprayers used in this study). The mixture was used to analyze and measure the forces applied to the driving lever of sprayers. The return average efforts required from the operator, as well as the efforts and number of cycles required both before and after reaching the $300 \mathrm{kPa}$ pressure were analyzed to know the pressure value to be maintained for 30 seconds during the work, as indicated by the ISO 19932-1:2013 standard.

The response variables were as follows: number of cycles, mean and maximum efforts $(\mathrm{N})$ to drive the lever, and effort time (s) to drive it in each cycle (pushing it from the top to the end and pulling it back to the top).

\section{RESULTS AND DISCUSSION}

The normality test was performed after the system reached the $300-\mathrm{kPa}$ pressure, and a significant normal distribution (Shapiro-Wilk test, $\mathrm{W})$ was obtained $(\mathrm{p}<0.05)$. Figure 2 shows that the dispersion $(\mathrm{CV})$ of mean values for the effort required to return the lever ranged from $0.03 \%$ (sprayer A) to $0.16 \%$ (sprayer F) (Table 1). The Shapiro-Wilk test (W) with the mean values for the return effort required for the pressure to reach 300$\mathrm{kPa}$ did not show a significant normal distribution $(p<0.05)$. A log transformation was applied to the data, which then showed a significant normal distribution $(\mathrm{p}>0.5)$.

Table 1 and figure 2 show the values for the return efforts required to operate the sprayers, and 


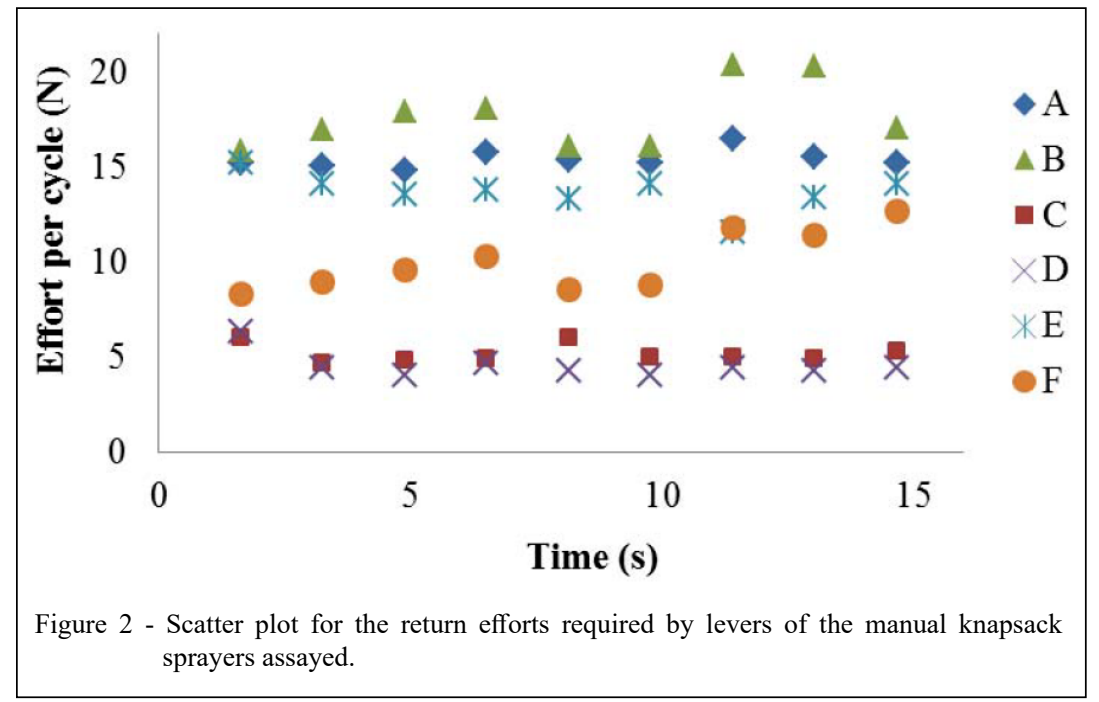

sprayer D showed the lowest value in this operation. For this sprayer, the mean $(4.6 \mathrm{~N})$ and maximum $(6.4 \mathrm{~N})$ values were very close to the mean value obtained for sprayer $\mathrm{C}(5.2 \mathrm{~N})$. The highest mean values for the operation effort were presented by sprayers $\mathrm{A}(15.4 \mathrm{~N})$ and $\mathrm{B}(17.6 \mathrm{~N})$. These values are about four times higher than the value obtained with sprayer D (significant difference at the 5\% level). Values for the average effort required to drive the $\mathrm{E}$ $(13.7 \mathrm{~N})$ and $\mathrm{F}(10.0 \mathrm{~N})$ sprayers also differed from each other, with the second highest value.

Results showed that the value for the maximum return (or ascending) effort required by the spray lever was given by sprayer B $(20.4 \mathrm{~N})$. The limit values for the maximum effort recommended for one of the upper limbs were indicated by CLT $(147.1 \mathrm{~N})$ and NASA-STD-3000B (53.6 N). Therefore, the maximum effort value for lever return $(20.4 \mathrm{~N})$ is below the limit values predicted by CLT and NASA-STD-3000B.
The lowest values for the mean and maximum efforts were given by sprayer $\mathrm{D}$. The increase in the value for the required effort, when compared to the effort values for Spray B (and given that the size of mixture particles is not homogeneous), may be associated with the existence of greater particles in the biofertilizer mixture that could impair fluid passage through the equipment nozzle, requiring a greater effort from the operator to emit the particles during spraying.

In table 2, it can be seen that the lower mean value for the operation efforts required to achieve the $300 \mathrm{kPa}$ pressure was provided by sprayer E $(11.4 \mathrm{~N})$. However, 16 cycles were required to achieve this pressure. This was due to the fact that increasing operation efforts at each cycle were required for this sprayer. Sprayer A required a lower number of movements (5 cycles) to achieve the $300 \mathrm{kPa}$ pressure. This shows that it has a higher pressure capacity per cycle when compared to other

Table 1 - Mean and maximum values for the return effort required to operate manual knapsack sprayers.

\begin{tabular}{lcccccc}
\hline Sprayers & A & B & C & D & E & F \\
\hline Mean values (N) & $15.4 \mathrm{~b}$ & $17.6 \mathrm{a}$ & $5.19 \mathrm{e}$ & $4.57 \mathrm{e}$ & $13.7 \mathrm{c}$ & $10.0 \mathrm{~d}$ \\
Maximum values (N) & 16.5 & 20.4 & 6.03 & 6.37 & 15.2 & 12.7 \\
$\sigma(\mathrm{N})$ & 0.47 & 1.72 & 0.50 & 0.71 & 0.97 & 1.60 \\
cv $(\%)$ & 0.03 & 0.10 & 0.10 & 0.15 & 0.07 \\
\hline
\end{tabular}

The averages followed by the same letter do not differ from each other ( $5 \%$ significance level). $\sigma$ : standard deviation; cv: coefficient of variation. 
Table 2 - Mean and maximum effort values and number of cycles required to achieve the $300 \mathrm{kPa}$ pressure in manual knapsack sprayers.

\begin{tabular}{lcccccc}
\hline Sprayers & A & B & C & D & E \\
\hline Mean values $(\mathrm{N})$ & $17.0 \mathrm{~b}$ & $74.1 \mathrm{a}$ & $23.9 \mathrm{~b}$ & $19.4 \mathrm{~b}$ & $11.4 \mathrm{~b}$ & $18.2 \mathrm{~b}$ \\
Number of cycles & 5 & 14 & 11 & 13 & 16 & 19 \\
Maximum values $(\mathrm{N})$ & 18.6 & 79.4 & 52.5 & 54.4 & 38.6 & 44.8 \\
$\sigma(\mathrm{N})$ & 1.94 & 2.88 & 14.93 & 17.07 & 11.39 \\
$\mathrm{cv}(\%)$ & 0.11 & 0.04 & 0.62 & 0.88 & 1.00 & 0.68 \\
\hline
\end{tabular}

The values followed by the same letter do not differ from each other ( $5 \%$ significance level). $\sigma$ : standard deviation; cv: coefficient of variation.

sprayers. It can be considered the most effective sprayer among the study models, also because it presented the second lowest effort value required for operation $(17.0 \mathrm{~N})$. Regarding the mean operation effort, significant differences were not observed between sprayers A $(17.0 \mathrm{~N}), \mathrm{C}(23.9 \mathrm{~N}), \mathrm{D}(19.4$ $\mathrm{N}), \mathrm{E}(11.4 \mathrm{~N})$, and $\mathrm{F}(18.2 \mathrm{~N})$. On the other hand, the mean value for the operation effort of sprayer $\mathrm{B}$ $(74.1 \mathrm{~N})$ is different from those of other sprayers, being about seven times greater than the lowest operation effort value obtained with sprayer E (11.4 N). Similarly, the maximum (downward) effort required by the lever was presented by sprayer $\mathrm{B}$ $(79.4 \mathrm{~N})$. The value for the operation effort required by this sprayer to reach the $300 \mathrm{kPa}$ pressure is above the limit values indicated by NASA-STD$3000 \mathrm{~B}$ for the left $(60.8 \mathrm{~N})$ and right $(71.2 \mathrm{~N})$ arms in descending motion.

Sprayers A, D, E, and F presented the best performances because the working pressure was achieved with a lower number of cycles and lower values for the maximum and average efforts. Again, this fact may be associated with the size of particles in the mixture in which much larger particles could cause a pressure increase, thus increasing the amount of cycles required.

Table 3 and figure 3 show the effort values after the pressure reached $300 \mathrm{kPa}$, and it can be seen that sprayer A showed lower mean $(16.4 \mathrm{~N})$ and maximum $(18.2 \mathrm{~N})$ effort values. Thus, we can state that sprayer A provides greater comfort to the operator. Regarding the mean values for the operation effort, sprayers $\mathrm{C}(70.7 \mathrm{~N})$ and $\mathrm{D}(79.5$ $\mathrm{N})$ did not differ significantly from each other. The other data showed significant differences by the Tukey's test (5\% level).

Our results showed that the maximum effort required by the sprayer lever was $90.9 \mathrm{~N}$ (sprayer D) after the $300 \mathrm{kPa}$ pressure was reached. The CLT recommends the limit value of $147.1 \mathrm{~N}$ as the effort limit for one of the operator's arms, and thus all sprayers evaluated in this study are in agreement with this standard. However, only sprayers A and F are within the standards if the limit value indicated by NASA-STD-3000B (1995; $71.2 \mathrm{~N})$ for the efforts of the operator's arm is considered.

Table 3 - Mean and maximum effort values required to operate the lever after the $300 \mathrm{kPa}$ pressure was reached in manual knapsack sprayers.

\begin{tabular}{lcccccc}
\hline Sprayers & A & B & C & D & E \\
\hline Mean values $(\mathrm{N})$ & $16.4 \mathrm{~b}$ & $74.3 \mathrm{a}$ & $70.7 \mathrm{e}$ & $79.5 \mathrm{e}$ & $60.4 \mathrm{c}$ & $50.5 \mathrm{~d}$ \\
Number of cycles & 11 & 11 & 11 & 11 & 11 & 80.3 \\
Maximum values $(\mathrm{N})$ & 18.2 & 86.0 & 81.7 & 90.9 & 11 & 14.10 \\
$\sigma(\mathrm{N})$ & 0.86 & 7.13 & 10.20 & 0.16 & 3.04 \\
$\mathrm{cv}(\%)$ & 0.05 & 0.10 & 0.14 & 0.23 & 0.06 \\
\hline
\end{tabular}

The values followed by the same letter do not differ from each other (5\% significance level). $\sigma$ : standard deviation; cv: coefficient of variation. 


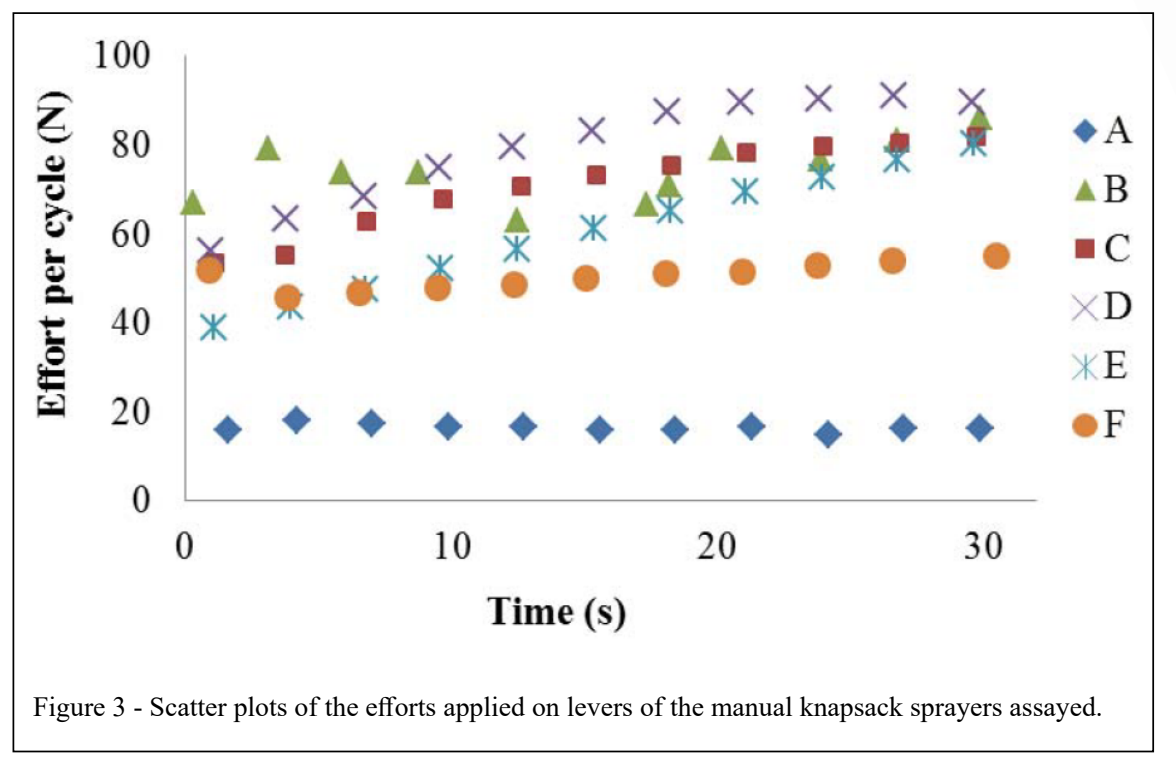

The values for the operation efforts measured in the sprayers are shown in the scatter plot (Figure 3). It can be seen that sprayer A also provides relatively similar values for the operation efforts as a function of time, in addition to requiring lower values. These results may be due to the fact that sprayer $\mathrm{A}$ is the most effective.

Conversely, the other sprayers required increasing operation efforts over time, presenting significantly high values for these efforts during their operation.

It can be seen that only return values showed similar values when compared with those reported by PHADKE et al. (1992). This may be due to the fact that the sprayers used at that time were distinct and operated with older technologies. Conversely, they are on the same magnitude scale when compared to the values published by LAMBRECHT et al. (2018). However, the force on the lever required to attain the $300-\mathrm{kPa}$ pressure is usually about twice when biofertilizer is used in relation to the highest values reported by LAMBRECHT et al. (2018) for the same operation with water.

\section{CONCLUSION}

All sprayers are in agreement with the CLT recommendations regarding the return effort and the necessary efforts before and after the $300 \mathrm{kPa}$ pressure were achieved.

Regarding the NASA-STD-3000B recommendations, all sprayers are in agreement regarding the maximum return effort; only sprayer $\mathrm{B}$ has failed regarding the maximum effort required to achieve the $300 \mathrm{kPa}$ pressure; and only sprayers $\mathrm{A}$ and $\mathrm{F}$ are in agreement regarding the maximum effort required by the sprayer lever after reaching the $300 \mathrm{kPa}$ pressure.

Sprayer A showed the most adequate result regarding the limit values recommended by both organisms.

\section{DECLARATION OF CONFLICT OF INTERESTS}

The authors declare no conflict of interest. The founding sponsors had no role in the design of the study; in the collection, analyses, or interpretation of data; in the writing of the manuscript, and in the decision to publish the results.

\section{AUTHORS' CONTRIBUTIONS}

All authors contributed equally for the conception and writing of the manuscript. All authors critically revised the manuscript and approved the final version.

\section{REFERENCES}

CARVALHO, C.C.S. et. al. Ambiente térmico e análise postural durante a aplicação de defensivos agrícolas no norte de minas gerais. Unimontes Científica, ISSN 2236-5257, v.15, n.2, 2013. Available from: <http://www.ruc.unimontes.br/index.php/ unicientifica/article/view/259/251>. Accessed: Feb. 11, 2018.

FREITAS, C. S. Análise ergonômica da atividade com pulverizador costal manual na cultura do café no município de Caratinga. 2006. 58f. Dissertação (Mestrado 
em meio ambiente e sustentabilidade) - Programa de PósGraduação em Meio Ambiente e Sustentabilidade, Centro Universitário de Caratinga. Available from: <http://www.scielo. br/scielo.php? script $=$ sci nlinks \&ref $=000074 \&$ pid $=$ S 1983 $4063201300030001500008 \& \operatorname{lng}=$ pt $>$. Accessed: Mar. 18, 2018.

INTERNATIONALORGANIZATIONFORSTANDARDIZATION. TC 23 Tractors And Machinery For Agriculture And Forestry. ISO 19932-1:2013: Equipment For Crop Protection - Knapsack Sprayers - Part 1: Safety And Environmental Requirements. Available from: <http://www.iso.org/iso/catalogue_detail. htm?csnumber=56031>. Accessed: Mar. 18, 2018.

LAMBRECHT, E, et al. Operator effort on the operation of the knapsack sprayer pumping lever.Eng. Agríc., Jaboticabal, v.38, n.2, p.238-243, abr. 2018. Available from: <http:// www.scielo.br/scielo.php? script $=$ sci_arttext\&pid $=\mathrm{s} 0100$ 69162018000200238\&lng=pt\&nrm=iso $>$. Accessed: Nov. 23, 2018. doi: 10.1590/1809-4430-eng.agric.v38n2p238-243/2018.

LOPES,E.S.etal.Determinaçãodacargafísicadetrabalhonaatividade de aplicação manual de herbicida. Ambiência, v.7, n.2, p.329-337, 2011. Available from: <HTTP://WWW.SCIELO.BR/SCIELO. PHP?SCRIPT $=$ SCI NLINKS\&REF $=000117 \&$ PID $=S 0100$ $76220140002000300008 \& \mathrm{LNG}=\mathrm{EN}>$. Accessed: Nov. 23, 2018. doi: 10.5777/ambiencia.2011.02.10.

NASA - NATIONAL AERONAUTICS AND SPACE ADMINISTRATION. Nasa technical standard: Man-systems integration standards (MSIS), NASA-STD-3000B, Volume I, p.4-13, 01 Jul. 1995. Available from: <HTTP://EVERYSPEC. COM/NASA/NASA-NASA-STD/NASA-STD-3000B_VOL1 16180/>. Accessed: Nov. 10, 2016.
PHADKE, S. M. etal. Test code and procedure for ergonomic evaluation of lever-operated knapsack sprayers. International Journal of Industrial Ergonomics. v.10, n.4, p.293-300, 1992. Available from: <HTTPS://DOI.ORG/10.1016/0169-8141(92)90096-I>. Accessed: Mar. 11, 2018. doi: 10.1016/0169-8141(92)90096-I.

SENAR, Serviço Nacional de Aprendizagem Rural. Trabalho Decente. Educação Postural no Campo: Trabalhador na Aplicação de Agrotóxicos. Brasília, 2014. 24p. Available from: $<$ HTTP://WWW SENAR.ORG.BR/SITES/DEFAULT/FILES/EP_APLICACAO_ DE AGROTOXICO_2014.PDF>. Accessed: Feb. 13, 2018.

SILVA, J. A. et al. Análise e avaliação da tecnologia de aplicação de defensivo agrícola na cultura da lichia. Revista Científica Eletrônica de Agronomia, ISSN 1677-0293. n.27, 2015. Available from:<HTTP://FAEF.REVISTA.INF.BR/SITE/E/AGRONOMIA27-EDICAO-JUNHO-DE-2015.HTML\#TAB1156>. Accessed: Dec. 26, 2016. doi: 10.5777/ambiencia.2011.02.10.

SOUZA, N. S. S.; SANTANA, V. S. Incidência cumulativa anual de doenças musculo esqueléticas incapacitantes relacionadas ao trabalho em uma área urbana do Brasil. Cad. Saúde Pública, v.27, n.11, Nov. 2011. Available from: <HTTP://WWW.SCIELO.BR/ SCIELO.PHP?SCRIPT $=$ SCIARTTEXT \&PID=S0102-311X2011 001100006\&LNG=EN\&NRM=ISO > . Accessed: Dec. 27, 2016. doi: 10.1590/S0102-311X2011001100006.

STUCHI, J. F. Biofertilizante: um adubo líquido de qualidade que você pode fazer. Brasília-DF: Embrapa, 2015. 16p. Available from: <HTTPS://WWW.INFOTECA.CNPTIA. EMBRAPA.BR/INFOTECA/BITSTREAM/DOC/1046948/1/ CPAFAP2015CARTILHABIOFERTILIZANTEFINAL.PDF>. Accessed: Feb. 11, 2018. 